\title{
Global Economic Governance Reenergized?
}

\author{
The Chinese Presidency of the G20 \\ in 2016
}

Ye Yu

\begin{abstract}
As China makes preparations to host the Group of Twenty (G20) summit in 2016, the international community is wondering whether the world's second largest economy can reenergize the G20, a key mechanism for global economic governance. With increasing stake in global economic well-being, China has developed a strong sense of commitment to the G20, and thus will put great efforts into making the mechanism more effective. However, both the Chinese and world economies are facing dual bottlenecks of efficiency and equality. How to tap new sources of growth, manage the fragmented regionalization, and create momentum for globalization will be the main challenges for the G20 next year and thereafter. What China should do is foster its leadership by better aligning its own reform and development strategy with the G20's global agenda for a
\end{abstract}

Ye Yu is Research Associate at the Shanghai Institutes for International Studies (SIIS) focusing on the study of China's multilateral economic diplomacy. This article was written during the author's research stay at the G20 Study Center of the Lowy Institute for International Policy based in Sydney, Australia in June 2015. Part of the piece appeared in the 17th issue of G20 Monitor under the title of "From Turkey to China: what lies ahead for the G20 in 2016?" published by the Lowy Institute for International Policy. Special thanks are due to Tristram Sainsbury and Hannah Wurf for their generous assistance.

(c) 2015 World Century Publishing Corporation and Shanghai Institutes for International Studies China Quarterly of International Strategic Studies, Vol. 1, No. 4, 647-665

DOI: 10.1142/S2377740015500293 
clearer vision of the global economic system. Priorities could include carrying out comprehensive structural reform, implementing infrastructure investment initiatives, upgrading global trade institutions, and drawing a road map for the implementation of the 2030 sustainable development agenda. To manage short-term market volatility in major economies, the adjustment of their monetary policies should also be given timely and sufficient attention.

Keywords: Global economic governance; Chinese presidency of the G20; Infrastructure investment; global trade; IMF reform.

\section{Introduction}

The Group of Twenty (G20), an international forum founded in 1999 to promote high-level discussion on global financial stability, held its inaugural summit meeting on November 15, 2008, in recognition of the need for major developed and emerging economies to work together in global economic governance. Gordon Brown, former UK prime minister, described the new body as offering "more chance of delivering results than anything since the Second World War." ${ }^{11}$ In the first couple of years, the performance of "the premier forum for international economic cooperation" was widely hailed for its quick response to the global financial crisis. Yet at the same time, many observers regarded the G20 as evolving "from early success to early aging" as it was unable to play any substantial role in urging the European countries to address the Euro crisis in $2010 .^{2}$ With its agenda expanded and function shifted from managing crises to steering growth and development, the G20 started to invite even more suspicion about its effectiveness. However, observers are more rational about the limitations of the G20's role. Just as one commentary elaborated, "as a process driver, a systemic risk manager and a bulwark against restrictive forms of unilateralism, this innovation remains indispensable," though it has to be "a combination of burden-sharing on joint endeavors and pluralism that

${ }^{1}$ Edward Luce, "New Body Takes on Economic Leadership," Financial Times, September 25, 2009.

${ }^{2}$ Bruce Jones, "The G-20 in Crisis? Or the G-20 on Crises?" in Kemal Derviş and Peter Drysdale, eds., The G-20 Summit at Five: Time for Strategic Leadership (Washington D.C.: Brookings Institution Press, 2014), p. 68. 
allows for national differences." ${ }^{3}$ Fundamentally, global governance can only play a complementary role compared to behaviors of major powers for the world order. ${ }^{4}$

A similar position is warranted in assessing the role of emerging economies in the G20 and global economic governance. It is a milestone for emerging economies to be able to take their equal seats and sit at the table of the G20 with advanced economies; their substantial role, however, is still relatively limited in some core issues from financial regulation to macroeconomic coordination. ${ }^{5}$ If what the G20 is nurturing is a long-term "grand deal" between advanced and emerging economies, the IMF quota reform package reached in 2010 could be seen as an "advance payment" by advanced economies in exchange for the flexibility of emerging economies in trade, exchange rate, climate, and future contributions to the IMF. ${ }^{6}$ So far the deal has turned out to be very difficult to push through.

It is against this background that China takes over the chairmanship of the G20. With the miracle of rapid economic growth since the 1980s, China has become the world's second largest economy and the largest trading partner of a majority of the world's major economies. Despite its global economic weight, China is still playing a relatively subsidiary role in shaping the global economic order. It is this obvious disparity that stimulates much imagination in the international community for a bigger role of China in the G20. Can China reenergize the G20 and global economic governance? This article argues that China has sufficient incentives to exhibit its global responsibility and make a significant contribution to the G20. However, we should not expect any major breakthroughs in reaching a new "grand deal." At best, China's contribution to the G20 could include a long-term vision and some progress in implementing the existing G20 agenda.

${ }^{3}$ Andrew F. Cooper and Paola Subacchi, “Overview,"International Affairs, Vol. 86, No. 3 (May 2010), p. 609.

${ }^{4}$ Thomas G. Weiss and Ramesh Thakur, Global Governance and the UN: An Unfinished Journey (Bloomington: Indiana University Press, 2010), p. 36.

${ }^{5}$ Changyong Rhee and Alok Sheel, "The Role of Emerging Economies in Major G-20 Initiatives," in Derviş and Drysdale, eds., The G-20 Summit at Five: Time for Strategic Leadership, pp. 45-66.

${ }^{6}$ Ibid. 
This article first outlines the G20's objectives as a forum and how the focus of the G20 has shifted over time from stability and crisis management to growth and longer-term economic development. It then details the highlevel economic backdrop that will underpin China's G20 Presidency next year. Finally, the article will explore some opportunities for world economies during the Chinese Presidency in 2016.

\section{Evolution of the G20's Triple-Level Agenda: Financial Security, Economic Growth, and Sustainable Development}

Since its inception, the G20 has been a loose forum without any formal organizational structure, its agenda setting mainly driven by host countries without any rules and limits, and thus its viability and accessibility have always remained in question. In spite of such shortcomings, we can still observe an evolutionary trajectory of the G20 agenda with the world's economic development in the past seven years.

The G20's core mission is to foster strong, sustainable, and balanced global economic growth. Theoretically, there are three "wheels" to be kept in balance for the healthy functioning of the global economic system: stability, efficiency, and equity. Corresponding to this tripartite division, the increasingly expanding and diverse G20 agenda items can be framed broadly as the pursuit of financial security, economic growth, and sustainable development - a convenient logic for making the premier forum for international economic cooperation comprehensible, both to the G20 officials and to the general public.

The first level of the G20 agenda, the financial security agenda, primarily refers to ad hoc macroeconomic coordination and the more systematic reform of the international monetary and financial system. Irrespective of the strategic role one expects from the G20, contingent macroeconomic coordination in response to emerging economic risks should be thought of as a routine aspect of the policy-making toolkit. The G20 may need to adapt itself to changing situations when managing crises, emergencies, and uncertainties such as financial market volatility or dramatic fluctuations in international oil prices. The stability agenda also includes IMF reform, the enhancement of financial regulation, and the global coordination to manage the spillover effects of changing monetary policy. 
The core focus within the second area, economic growth, concerns the implementation of structural reforms that address the myriad factors to increase global supply as well as global demand. As leaders acknowledged in Brisbane in November 2014, the global economy is being held back by a shortfall in demand, while addressing supply constraints is key to lifting potential growth. Countries have committed to a wide range of regulatory and institutional policies that boost consumption, increase trade, promote investment, particularly in infrastructure, and reform the labor markets.

The third level of the G20's agenda - sustainable development - is the broadest one. It concerns how to ensure that economic growth is more balanced, inclusive, and sustainable in the long term. A gradual shift has occurred in the argument on balancing efficiency and inequality, that is, rising social inequality has been increasingly recognized as an obstacle to growth and development, as evidenced by the popularity of Thomas Piketty's Capital in the Twenty-First Century. ${ }^{7}$ The threat of environmental degradation and climate change has also undoubtedly surfaced at the top of

The G20 is primarily

a platform to address long-term global macroeconomic issues rather than seek short-term solutions. the global development agenda.

In the immediate aftermath of the financial crisis, and consistent with its elevation to a leader-level summit, the G20 was nearly occupied by short-term financial security agenda, and it focused on coordinating the rescue of the banking system severely plagued by the subprime mortgage crisis that originated in the United States in 2008, mobilizing resources for insolvent sovereign countries in the Euro crisis in 2010, overhauling the global financial regulatory system, and pushing for reforms of international financial institutions (IFIs). The measures that the G20 countries had collectively taken to stimulate demand, the standstill of protectionism on trade, and actions to make the financial system secure and strengthen global financial institutions, earned the G20 a good reputation,

${ }^{7}$ Thomas Piketty, Capital in the Twenty-First Century (Cambridge, Mass.: Belknap Press, 2014). 
though the financial regulatory reform process and the unfinished IMF reform project left a lot of questions unsolved.

Since the world economy stepped away from crisis response to a persistently weak recovery, the focus of the G20 agenda has correspondingly shifted from crisis management to the promotion of medium- and long-term growth and development. While multilateral trade efforts have made little progress and the global trade agenda has become increasingly dominated by an ever-increasing number of bilateral and regional initiatives, infrastructure investment has emerged as one of the top issues on the G20's growth agenda. The G20 is also gearing up structural reforms of its members at the supply end for more sustainable growth, but different members may have different priorities, for example, China needs to ensure that the market plays a decisive role in allocating resources while many advanced economies would like to put their fiscal consolidation plans right. ${ }^{8}$ Driven by the need to mobilize more revenues, the United States and European countries have successfully globalized their efforts in cracking down on tax havens through the G20 platform. Capacity building for African and other developing countries in this aspect has also been brought to global attention.

Although the UN remains the main channel for global negotiations on international development cooperation after 2015, aspects of the development agenda have incrementally entered the domain of the G20, including issues of energy and climate, since 2010. Inclusive development is a highlight of this year's G20 summit in Turkey, with special focus on the issues of gender as well as small and medium-sized enterprises. In order to streamline the development agenda, Australia instituted the G20 Development Working Group Accountability Framework in 2014 during its presidency of the G20. ${ }^{9}$

In sum, the G20 seems to be prepared to handle some long-term topics while keeping alert on short-term issues. Fundamentally this is because the world economy is still facing the triple constraints of stability, efficiency, and equity, which have led to weak and uneven growth. This most

${ }^{8}$ OECD, “Economic Policy Reforms: Going for Growth 2014,” http://www.oecd.org/ eco/goingforgrowth.htm.

9 “G20 Development Working Group Accountability Framework," September 5, 2014, https:// g20.org/wp-content/uploads/2014/12/g20_development_working_group_accountability_framework. pdf. 
comprehensive agenda structure is expected to be a legacy for China's G20 presidency in 2016. The next section of this article will look into some recent developments and future trends in both global economic situations and the global economic governance structure that may further shape the directions of China's G20 presidency next year.

\section{G20 Summit: From Washington, D.C. to Hangzhou}

In the near term, the weak and uneven recovery of the world economy is expected to continue, while momentum is shifting toward developed economies. Recently, the IMF forecast for global growth was 3.3 percent in 2015 and 3.8 percent in $2016 .{ }^{10}$ Situations in the developed economies are

The predominant task for the G20 in the next few years will be to ensure lasting global economic growth while coordinating integration processes of various regions. improving, while the growth rates in the majority of emerging and developing countries are slowing down. ${ }^{11}$ Most significantly, the Chinese economy is widely estimated to further its adjustment to a "new normal" with a decelerated growth rate to little more than six percent in 2016. ${ }^{12}$ During this process, the world economy will be threatened by various risks and uncertainties, such as changes in monetary policy, volatile financial and commodity markets, prolonged uncertainty in the Eurozone, and the deterioration of geopolitical conflicts.

With regard to some long-term global economic governance issues, comprehensive regionalization in trade, investment, and development will remain the priorities of major economies. It is predicted by leading trade economists that since the Doha Round is

${ }^{10} \mathrm{IMF}$, World Economic Outlook Update (Washington, D.C.: International Monetary Fund, July 2015), http://www.imf.org/external/pubs/ft/weo/2015/update/02/.

${ }^{11}$ The World Bank Group, Global Economic Prospects, The Global Economy in Transition (Washington D.C.: World Bank, June 2015), http://www.worldbank.org/content/dam/ Worldbank/GEP/GEP2015b/Global-Economic-Prospects-June-2015-Global-economy-in-transition.pdf.

${ }^{12} \mathrm{IMF}$, World Economic Outlook Update. 
unlikely to conclude before 2020, providing slim chance for WTO engagement in supply-chain issues, the landscape of world trade governance will be further fragmented. ${ }^{13}$ Prominent examples in this regard may include the most recent victory on the Trade Promotion Authority (TPA) by the Obama Administration, which will accelerate the legalization of the TransPacific Partnership (TPP) in the U.S. Congress. Besides, negotiations on the China-U.S. Bilateral Investment Treaty, the Regional Comprehensive Economic Partnership (RCEP), and the Transatlantic Trade and Investment Partnership (TTIP) are also under way. Meanwhile, there are other ongoing bilateral or regional initiatives. China and ASEAN are expected to upgrade their bilateral Free Trade Area Agreement by the end of 2015. The launch of the Asian Infrastructure Investment Bank (AIIB) and the BRICS New Development Bank (NDB) has created a strong momentum for a new round of competition over regional and cross-regional development banks.

Despite the grand trend of regionalization, some major global gatherings have taken place immediately before or as the Chinese Presidency commences: the UN Post-2015 Development Agenda was adopted by the UN General Assembly in September 2015, and the United Nations Framework Convention on Climate Change (UNFCCC) Conference of the Parties negotiations are underway in Paris (COP 21). All these summits could set some key milestones for future global cooperation. However, the real challenge is the delivery of the outcomes. Lack of implementation will shake public confidence in multilateralism, the G20, and the world's ability to deal with pressing issues. This comes at a time when competitive mega-regional arrangements are gaining momentum, as evidenced by recent advances in reaching the Trans-Pacific Partnership and other mega-regional trade deals, as well as the progress made by the AIIB and the NDB in investment.

In short, how to tap new sources of growth and manage the fragmented regionalization and create momentum for globalization will be the main challenges for the G20 in the next year and thereafter.

\section{China's Presidency: Significance and Realistic Expectations}

It is doubtless that its G20 membership has already encouraged China to participate in global economic governance more actively in the past seven

${ }^{13}$ Piketty, Capital in the Twenty-First Century. 
years. China has played its part in the G20 by providing financial resources that would shore up the world economy, and has been supporting initiatives that garner a broad consensus. China has also worked together with the other BRICS countries to push forward reform of the Bretton Woods System since 2009, and with the U.S. and Australia for the writing of G20 Principles on Energy Collaboration since 2014.

However, China's role has been generally limited so far. In terms of the financial regulatory reform that has dominated the G20 agenda until now, China has mainly been a follower. In the macro-economic coordination process around 2010, China was in discord with the G20's efforts on setting quantitative targets for its national trade surplus and other indicators. China was unable to break the stalemate of reform on global economic

With higher stakes and a bigger role to play, China's presidency of G20 will render it with a stronger sense of commitment to global economic governance. institutions.

There are high hopes for China's G20 presidency in 2016, which will give China a stronger sense of commitment to global economic governance, and make China more willing to contribute to multilateralism for the world's benefit. There are three forms of leadership in international institutions: structural, entrepreneurial, and intellectual. ${ }^{14}$ If "middle powers" like South Korea and Australia provide a significant source of entrepreneurial and intellectual leadership within the G20, China as a major power can be expected to play a more comprehensive role. We need to bear in mind that China's contribution to global public goods is closely related to how China implements its own strategy; in the meantime, China needs to be more proactive intellectually and entrepreneurially.

Therefore, China's presidency in 2016 is widely considered as a chance for the G20 to be reenergized. This expectation is reasonable given that the chance can be an incentive mechanism catalyzing the following effects: First, a stronger sense of ownership on the part of China with regard to global

${ }^{14}$ OECD, “Economic Policy Reforms: Going for Growth 2014.” 
economic governance. As the rotating chair nation of the G20, China is more willing to contribute to the benefit of global order. At the early stage of China's participation in the G20, its contribution was mainly about financial resources in shoring up the world economy and injecting liquidity to the IMF in order to relieve the Euro crisis. During its presidency, China is expected to go beyond simply setting aside more money; instead, China is likely to provide more ideas and proposals about the future of global economic governance.

Second, better alignment of Chinese unilateral, bilateral, and regional strategies with the G20's global agenda. Multilateral platforms are basically about managing spillover effects of policies from major economies and protecting interests of smaller countries. China still identifies itself as a developing country, yet it does shoulder an increasing burden for the world economy and its strategic choices will have systematic impacts on other countries. Hence it is necessary for China to take other countries into consideration while deliberating its own policies. The G20 may be a perfect chance to encourage China to make decisions from a global perspective.

Third, closer communication between China and the world. The G20 is not only an inter-governmental forum, but also a multi-level platform to mobilize the Chinese people to express their views and support global economic governance. Unfortunately, there is no solid consensus yet among Chinese people on the role of their country in global economic governance; the G20 presidency may help increase awareness and preparedness of the Chinese public, which could also provide a perfect chance for Chinese think tanks, universities, companies, as well as individuals to speak to the world about a diverse Chinese society through Business 20, Think 20, and Civil 20, etc. The significance of this aspect should not be overlooked considering the deep misunderstanding and distrust that exists between China and the outside world.

Last but not least, stronger pressure for better implementation of the Chinese domestic reform agenda. It still holds true that managing domestic affairs is China's first and most important contribution to the world. The G20 can be a new external authority for China to push forward its domestic reform agenda. It is in the interest of China and the world as well.

Despite these potential catalyzing effects, we should not assume that a grand deal can be achieved in China's G20 presidency next year. In the slow and long evolving process of the G20, we have to realize that China's 
leadership is somewhat complicated and ambiguous. Though it has risen to be the world's second in terms of economic size, China still faces enormous domestic challenges in both the short and long term. It keeps a defensive mindset on the spillover effects of many key economic issues, as is the case for many developing countries. It is also facing more difficulties when dealing with the global South due to its competitiveness in labor-intensive industries. Fundamentally, China's current position in the world-big in aggregate but weak in structure-defines its influence in the G20. This position is characteristic of a coexistence of both ambition and ambiguity, both strength and weakness. ${ }^{15}$ Culturally and ideologically, it is an oriental and socialist country. Lack of international experience and the uniqueness of its political system also limit China's role in the G20. ${ }^{16}$ Competition, conflicts, misunderstanding, and suspicion interwined with each other would render the Chinese chairmanship much more complicated than that of previous G20 chair nations. It may be too early to talk about China's global leadership before it establishes some kind of regional or crossregional leadership (for instance, in BRICS). The AIIB or BRICS NDB is only a starting point. Above all, next year's G20 is first a platform for trust building, and subsequently for facilitating policy coordination of major

One should not

expect the G20

Summit 2016 to

achieve too much

either in

strengthening the global economy or in promoting China's status in global economic governance.

\section{economies.}

There is also a risk that, as the U.S. presidential election at the end of 2016 looms large, it may become a political distraction for progressing substantive reform during next year's G20. There is a joke among some G20 experts that "all G20 members are equal, although some are more equal than others," which usually refers to the importance of understanding the U.S. position on agenda items. All major issues on the G20 agenda, including finance, currency, tax, trade, and development are still very dependent on the attitude and role of the U.S., but at a time of increasing anti-globalization sentiment, the

15 “G20 Development Working Group Accountability Framework.”

${ }^{16} \mathrm{IMF}$, World Economic Outlook Update. 
U.S. presidential candidates usually choose to court domestic voters and interest groups at the expense of the global agenda. Therefore, China will need to be skillful in the way it negotiates with other G20 members, especially the U.S., in trying to build a consensus and manage its priorities.

\section{G20 with a Vision: China's Priorities for Its 2016 Presidency}

China's presidency will need to do three things simultaneously in filling in the five gaps in knowledge, norms, policy, institutions, and compliance in global economic governance: ${ }^{17}$ First, to implement past commitments; second, to push forward unsolved issues on the core economic agenda; and third, to be ready to react to unexpected situations. This will require political will as well as innovative ideas rather than adding more items to the existing agenda list. Some of the possible areas that China can address in each of the stability, growth, and development agenda are explored below.

\section{Stability Agenda}

Macroeconomic coordination and preparation for uncertainties

As mentioned above, the world economy is facing a lot of uncertainties and risks, from the major economies' monetary policy adjustments, volatility of commodity markets to geopolitical risks. Emerging and developing economies including China need to be better prepared for external risks while dealing with their domestic challenges. The G20 members should enhance communications about the prospects of their national policies and some potential spillover effects on the world economy. Besides, discussions on global financial safety net should go beyond the IMF and regional financing arrangements

Other than

enhancing the organizational efficacy of the G20, China must take the lead in addressing the three imperative global agendas: stability, growth and development.

${ }^{17}$ The World Bank Group, Global Economic Prospects, The Global Economy in Transition. 
(RFAs) and the role of increasing bilateral currency swaps in crisis response should be fully appreciated. China is an active player in signing bilateral swaps in local currencies. By April 22, 2015, China had signed 30 swap arrangements with a total amount of RMB 3.1 trillion. $^{18}$

\section{Financial regulatory reform}

The G20 has made significant progress in responding to the causes of the global financial crisis over the past seven years. However, the implementation of financial regulatory reform is still uneven and therefore should be made a priority. ${ }^{19}$ Another issue is that the reform process was short-sighted and mainly a transatlantic negotiation with very little participation from emerging and developing countries like China. As financial regulation applies to all countries, China and other emerging economies in the G20 need to have a bigger role in the Financial Stability Board (FSB) and in assessing the impacts of the new rules on the developing world.

\section{"Plan B" for the IMF reform}

The G20 has made relentless efforts to push forward a breakthrough in the 2010 IMF reform package, even during the Australian and Turkish Presidencies, but to no avail. China would be unlikely to be more persuasive in changing the minds of the U.S. Congress, particularly during the potentially polarizing and domestically-focused U.S. election campaign. There has been strong rhetoric from the memberships of the G20 and the international monetary and financial committee about pursuing alternatives to IMF reform, while to date there is no feasible or pragmatic "Plan B." The IMF reform seems destined to remain in limbo in 2016.

Yet even if no progress is made, the issue of IMF governance is expected to be an important one for China's G20 Presidency in 2016. The prospect of an indefinite stasis in reform due to the U.S. congressional

${ }^{18} \mathrm{IMF}$, World Economic Outlook Update.

${ }^{19}$ Richard Baldwin, “WTO 2.0: Thinking Ahead on Global Trade Governance," CEPR Policy Insight No. 64 (London, UK: Centre for Economic Policy Research, December 2012). 
deadlock causes a new headache for IMF reform negotiators: deciding what to do about the $\$ 369$ billion in bilateral loans that will expire in late 2016 and early 2017 is currently the IMF's second line of defense. ${ }^{20}$ At the same time, broadening the IMF's special drawing rights currency basket to include the renminbi (RMB) seems to be a compromise that both the IMF and China need. This is a symbolic step rather than real reform of the IMF, which will not involve capital increase and could face lower hurdles for agreement. Nevertheless, if the issue is classified as "a change in the principle of valuation or a fundamental change in the application of the principle in effect," ${ }^{21}$ the approval of the U.S. is still vital for the 85 percent majority voting power. It is estimated that there is a 60 percent possibility that the RMB will be added to the SDR basket this year. ${ }^{22}$ A compromise could further accelerate the SDR review in 2016 or 2017 if the technical criteria are not met in time for the 2015 review.

Tristram Sainsbury has advocated for China's use of its G20 presidency to champion the process of negotiating a new round of bilateral loans necessary to bolster the IMF's firewall, arguing that China will go a long way to assure the international community of its seriousness about being a responsible stakeholder. ${ }^{23}$ With its presidency of the G20, China should refrain from hasty steps in reforming the international financial architecture and promoting destructive alternatives as part of the broader global financial safety net. Instead, it should focus its attention on the inclusion of the RMB in the IMF's SDR basket and adopt a constructive approach to discussions on IMF resourcing and the renewal of bilateral loans.

${ }^{20}$ Oran R. Young, “Political Leadership and Regime Formation: On the Development of Institutions in International Society," International Organization, Vol. 45, No. 3 (Summer 1991), pp. 281-308.

${ }^{21} \mathrm{Ye} \mathrm{Yu,} \mathrm{"China} \mathrm{and} \mathrm{the} \mathrm{G20,"} \mathrm{in} \mathrm{Catrina} \mathrm{Schlager} \mathrm{and} \mathrm{Chen} \mathrm{Dongxiao,} \mathrm{eds.,} \mathrm{China} \mathrm{and}$ the G20, The Interplay between an Emerging Power and an Emerging Institution (Shanghai: Shanghai People's Publishing House, 2015), p. 29.

${ }^{22}$ Huang Yiping, "The Chinese Economy and the Future of the G-20," in Derviş and Drysdale, eds., The G-20 Summit at Five: Time for Strategic Leadership, pp. 247-248.

${ }^{23}$ Weiss and Thakur, Global Governance and the UN: An Unfinished Journey, p. 36. 


\section{Growth Agenda}

The year of 2016 will witness the half-way point of the ongoing process to boost the G20 output by 2 percent by 2018 through structural reforms. A key juncture in the G20's efforts to implement the growth strategies that leaders outlined in Brisbane will be the first annual IMF/OECD progress report delivered to leaders in Antalya, Turkey in November 2015. The Chinese leadership will be key to ensuring that the G20 members respond positively to the findings and actively search for new policy commitments. China will need to be proactive in ensuring that the G20's commitments in this crucial area are not simply rhetoric.

There are three further ways by which China can boost the growth agenda:

- Showcase a number of bankable infrastructure projects. As mentioned above, infrastructure has emerged as a focal issue for growth in the G20, with significant progress made on domestic actions through Australia's country growth strategies and Turkey's investment strategies, as well as the multi-year infrastructure initiative. It is also a probable issue that unites the interests of G20 countries, and there is domestic resonance in China through the "Belt and Road Initiative." The most prominent and challenging aspect is how to align interests between public and private investors. Based on previous G20 outcomes, China may do most by taking advantage of its own experiences and practices to help prioritize the development and implementation of the pipeline of bankable infrastructure projects that could showcase the G20's relevance. This approach may have some particular added value for the G20's Global Infrastructure Hub, the World Bank's Global Infrastructure Facility, and the other two new multilateral banks: the AIIB and the BRICS New Development Bank.

- Set a vision for the global trade and investment regime. It is unlikely that the WTO negotiation process will be revived in the short term, although it remains clear that changes in the negotiating structure of the WTO are essential if the organization is going to deliver trade-promoting multilateral deals in the future. However, current priorities of the major economies are to conclude regional and bilateral initiatives, including the TPP, TTIP, RCEP, and the China-U.S. Bilateral Investment Treaty (BIT), among others. In 2016, China could direct the G20 to provide a vision for the future trade agenda, with the achievement of last year's APEC in 
advocating the Free Trade Area for the Asia Pacific Region (FTAAP) further expanded to the G20 level: to plan a road map to WTO version 2.0. For example, Professor Justin Lin proposes that China initiates a discussion on the Multilateral Investment Treaty for Development during its G20 presidency next year. ${ }^{24}$

- Promote innovation on the supply side for higher potential growth. Another aspect of growth that deserves greater attention and promotion is structural reform and innovation. The G20 cannot seek commitments from its members on this divisive issue, but more knowledge sharing and communication will be beneficial. A group of influential scholars in China have coined a "new supply-side school" of economic theory with a focus on institutional reforms. The core issue is to let the market play a more decisive role in allocating resources and let the government play a better role in providing public services. Six major points are emphasized, i.e., large scale tax reduction, elimination of redundant red tape, elimination of industry monopolies, reform of state-owned enterprises, liberalization of pricing of resources, and cost reduction of infrastructure and basic services. ${ }^{25}$

\section{Development Agenda}

Links between the development agenda and the G20 agenda have been forged in a piecemeal manner in the past. Building on the development part of Turkey's G20 agenda in 2015, China may seek a longer-term legacy by introducing a more systematic approach to further integrate development into the G20 agenda.

China's chairmanship in 2016 can drive forward progress in two primary areas. The first is to formulate a road map and timetable for the implementation of the 2030 Agenda for Sustainable Development and the Paris agreement on combating climate change. The G20 should not attempt to circumvent the leading role that the United Nations plays in either of

24"Shuju jianbao: zhongguo yi qianshu de shuangbian huobi huhuan xieyi yilanbiao [Data Briefing: A Survey of China's Bilateral Currency Swap Agreement]," Huanqiuwang, April 22, 2015, http://world.huanqiu.com/hot/2015-04/6259515.html.

${ }^{25}$ Malcolm D. Knight, "Reforming the Global Architecture of Financial Regulation, The G20, The IMF and The FSB," CIGI Papers No. 42 (Waterloo, Canada: Centre for International Governance Innovation, September 2014). 
these processes; instead it needs to take the "relay baton" and use its comparative advantages in political leadership to ensure the implementation of the 2030 Agenda as well as the Paris agreement. ${ }^{26}$ For example, as suggested by Barry Carin of Canada's Center for International Governance Innovation at the Think 20 event in February 2015 in Istanbul, the G20 may be a good platform from which four to five goals out of the 17 sustainable development goals can be selected and focused on, with the aim of leveraging on collective political will to make the road map more reliable.

The second is to pursue more inclusive global energy governance. ${ }^{27}$ The G20 is well placed to consider possible and different governance scenarios about the future of global energy governance and to articulate a vision for how governance arrangements should look over the long term. In Brisbane, the G20 member countries acknowledged that the international energy architecture has failed to keep pace with rapid transformations in international energy markets. Leaders endorsed principles on energy collaboration and requested their energy ministers to meet and advise on options to take these principles forward. This discussion brings together major energy producers and consumers around the table.

The ultimate challenge that the G20 faces is how to turn its commitment and principles into action, which requires political leadership. The G20 may ignite discussion on this and China, as the largest energy consumer and a key energy importer, would be well placed to drive forward that discussion. Restructuring or revamping the International Energy Agency (IEA) seems to be a reasonable, middle-ground proposal, and preferable to a more transformative and ambitious process of establishing a new global energy organization. The IEA's multilateral association process was disrupted by the Ukraine crisis, while its bilateral engagement with China and other emerging economies (except Russia) are still continuing. However, any future enlargement of the IEA membership needs to tackle a very fundamental treaty amendment issue. There are obstacles on both sides of the IEA and emerging economies. On the side of emerging economies, the OECD membership and oil emergency preparedness may be two major obstacles, while on the IEA side, there is also a fundamental treaty issue. The IEA's voting power structure is based on oil consumption of its

${ }^{26}$ Tristram Sainsbury, Lowy Institute Analysis Paper (forthcoming).

${ }^{27}$ IMF Articles of Agreement, 2011 edition, Art. XV. 
member countries. The energy landscape has evolved dramatically with the weight of consumption having shifted from the West to the East. The extent to which the U.S. and European countries are willing to give up their rights is still an open question. Chinese Premier Li Keqiang visited Paris in late June 2015 to deepen cooperation between China and the OECD, which may help advance China's ties with the IEA. China's G20 presidency next year might be a great chance to further its cooperation with the IEA.

The G20 held its first Energy Ministers' Meeting in October 2015. There are other aspects that could be pursued in pushing forward the G20 Principles on Energy Collaboration for sustainable energy security through mainstreaming the energy agenda into the G20, such as enhancing attention on the energy infrastructure for sustainable development and setting some quantitative targets for adopting renewable energy.

\section{Improving the G20 Preparation Process}

How to improve the efficiency of the G20 has been an ongoing topic. Despite a lot of warnings from academia that the G20 should keep its agenda focused, the expansion of the G20 agenda is almost inevitable. The G20 is regarded as a member-driven mechanism wherein each chair nation has strong incentives to add something new to the agenda. The issue is how to mainstream the process and make it more efficient and effective. The idea of establishing a permanent secretariat favored by the OECD was silenced in the G20 Summit in Cannes, France, in 2011. The Troika mechanism inherited from the G20 Finance Ministers' Meeting continues to support the G20 preparation process. However, there is much space for improvement. For example, Carin and Ye propose the following choices: transforming Troika into a Quintet with the United States and China as permanent members; merging Sherpa \& Finance Deputy tracks; selecting G20 Presidencies for the next five years; consolidating outreach into a single Davostype event; inviting reports for future meetings; de-emphasizing accountability; and inviting as few international organizations as possible (to prevent the G20 from becoming a talk-shop) ${ }^{28}$ Carin suggests establishing a non-secretariat that moves to the chair country of the G20 Summit every

28“Zhada: Renminbi Jinnian bei Naru SDR de Kenengxing wei 60\% [RMB has 60\% Likelihood of Inclusion in IMF's SDR Basket This Year: Standard Chartered]," NetEasecom, June 10, 2015, http://money.163.com/15/0610/07/ARNUTN5500251LBO.html. 
year and loans officials and elite cosmopolitan experts for the duration of a year. ${ }^{29}$ All the above suggestions on further institutionalization of the G20 mechanism are expected to be explored at the summit next year.

\section{Conclusion}

In 2013, Chinese State Councilor Yang Jiechi summarized the role of China in global economic governance as "active participant, supporter and contributor." ${ }^{30}$ When China takes its turn to chair the G20, its role as a contributor will be naturally magnified.. First and foremost, leading by example, i.e., aligning its national, regional or cross-regional strategies with the global agenda in a responsible way, will still be the major approach through which China contributes to global economic governance. Second, China is not in a position to reverse the grand trend of regionalization, while it does have the capacity to provide more strategic vision for the forum. Third, China's role in the G20 will certainly go beyond the year of 2016, and China should further play its part through the Troika or other coordinating mechanisms to realize the vision the G20 will set for the next year. Still, as the old saying goes, "man proposes, but God disposes." Despite all of China's efforts, observers on China's G20 presidency will need to be patient in waiting for its outcomes.

${ }^{29}$ Tristram Sainsbury, Lowy Institute Analysis Paper (forthcoming).

${ }^{30}$ Lin Yifu, "Lin Yifu: Zhongguo de G20 Yicheng: Huyu Yige Fazhan wei Mubiao de Duobian Touzi Kuangjia [Justin Lin: The G20 Agenda under Chinese Presidency-Call for a Multilateral Investment Framework for Development]," July 23, 2015, http://www.aiweibang.com/yuedu/caijing/39568633.html. 